\title{
Identity of certain species of plants of unknown source from Rasendramangala
}

\author{
Review Article
}

\section{Alekya $K^{1^{*}}$, Bulusu Sitaram², Pavan Kumar $S^{3}$}

1. PG Scholar, 2. Professor, 3. Assistant Professor, Department of Dravyaguna, S.V. Ayurvedic College, Tirupati,

\begin{abstract}
Combination of plant and mineral products were derived in the process of exploring safe and effective remedies which can cure severe and deadly diseases. Some plants are used for processing, purification and calcination of minerals, metals and gems. Mainly the purpose of plants in Rasa shastra is to obtain absorbable metallic molecules in the maximum possible minute form. But some plants mentioned in textbook of Rasa-shastra are not identified properly, because Rasa siddhas like Nagarjuna and Rasa Vagbhata have used some rare synonyms of plants, to conceal them from the knowledge of unknown and mischievous personalities, to avoid misuse. But at present, it is necessary to identify them properly, to use the plants for exact calcination and purification for the benefit of mankind. In the present study, nearly ten plants out of 47 unidentified plants are selected from Rasendra Mangala written by Acharya Nagarjuna in the period of $7^{\text {th }}$ and $8^{\text {th }}$ Century A.D. and a trial has been made to work out on such unidentified plants depending upon their synonyms, utility and combination with other drugs. To quote some, Kanchuki, Chandali, Choraka, Chandravalli and Sarpakshi.
\end{abstract}

Keywords: Nagarjuna, Rasa-Vagbhata, Rasendra Mangala, Plants of unknown source, Kanchuki, Choraka.

\section{Introdcution}

Rasa-shastra is a specialized branch of Ayurveda which mainly deals with the pharmaceuticals of unique and potent preparations. Metals and minerals are the integral part of Ayurvedic therapeutics along with herbal preparations. Use of metals in medicine is often associated with toxicity, but Ayurveda made them into biocompatible form by the use of certain plants for processing, colouring (coating) and certain detoxification processes like Shodana (Purification), Marana (Incineration), Bhavana (Trituration) etc. which removes the toxic effects and calcination of minerals, metals and gems. Mainly the purpose of plants in Rasa-shastra is to obtain absorbable metallic molecules in their maximum possible nano form. Recent studies reveal the synthesis of silver nanoparticles using leaf broth of medicinal herb, Tulasi (Ocimum sanctum Linn).(1) But some plants mentioned in lexicons of Rasa-shastra have not been identified properly, because Rasa siddhas like Nagarjuna and Rasa-Vagbhata have used some rare synonyms of plants to conceal them from the knowledge of mischievous personalities to avoid misuse.

Acharya Nagarjuna was pioneer and contributed a lot in this field and he is recognized as the Father of Rasa-shastra. Among many of his works Rasaratnakara, Rasendra Mangala, Kaksha Puta, Kubjika Tantra, Ascharya Yogamala, Loha shastra etc. are claimed to be contributed by Acharya Nagarjuna.

In the present study the famous text book Rasendra Mangala, written by Acharya Nagarjuna in

*Corresponding Author:

\section{Alekya K}

PG Scholar,

Department of Dravyaguna,

SV Ayurvedic College, Tirupati

Email id: alekhya.hiya92@gmail.com the period of $7^{\text {th }}$ to $8^{\text {th }}$ Century A.D is considered for studying medicinal plants used in Rasa-shastra. The original manuscript has eight chapters. The published book of Rasendra Mangala with Gurjari commentary by Professor Mishra B.D and Mishra D.K containing first 4 chapters are considered for the present study as the original manuscript was not published. According to Prof. P.V. Sharma, the remaining part (last four chapters) of this book is available in Asiatic society library, London.(2) In this treatise, nearly 400 plants are used. Out of them, maximum number of plants are commonly found all around the country. But to our dismay, there are many plants which are of doubtful identity. They are botanically not identified well and the synonyms used are leading us to a state of confusion, which is a real handicap to the workers and students of Rasa-shastra.

Keeping this fact in mind, a trial has been made to work out on unidentified plants in the full length, depending upon synonyms, utility and combination to bring them into the streamline which definitely helps the enthusiastic workers in processing metals and minerals.

\section{Aims and Objectives}

- To work out on some unidentified plants of Rasendra Mangala.

- To rule out the controversy of the synonyms leading to confusion based on the context of their utility and combination with other drugs in the processing of metals and minerals, depending upon other Ayurvedic literature and modern day work on the subject.

- To finally propose the botanical identity of some of the drugs with more probable species.

\section{Materials and Methods}

The study was done on Acharya Nagarjuna's Rasendra Mangala which is one of the great works on 
Rasa-shastra. Plant drugs which are of unknown identity are leading to a state of uncertainty as these procedures are meant actually to cure the ailing patients using them therapeutically. So, the plant drugs mentioned in Rasendra Mangala are enumerated and their identity is established by comparing them with the known literature.

Samhitas and their respective Commentaries, Nighantus (Bhavaprakasha Nighantu, Dhanvantari Nighantu, Raja Nighantu, Kaiyadeva Nighantu) and also books on Rasa-shastra (Rasa-Ratna-Samucchaya, Rasa Paddhati) have been referred for the study of this topic and discussion is based upon its conceptual part to bring out final conclusion. The study has been limited to the available literature at our purview. The unidentified plants list is tabulated and tried to resolve the most probable source for the maximum possible drugs which will be discussed further.

\section{Observations}

This text contains nearly 400 plant drugs along with rasoushadhas (mineral drugs), among which 47 plants are of unknown identity. The List of the 47 plants which are unidentified are Amari, Bhulatha, Chandali, Chandravalli, Choraka, Damayanti, Dinari, Dvipadi, Ghanaka, Ghanira, Ghatodbhava, Gopalika, Gouriphala, Gopendra, Halottamakhya, Hasthikarni, Javichi, Kalashi, Kanchuki, Kanjira bija, Kharasika, Kiratundi, Kitarani, Koyala, Krutamada, Kutheraka, Madamudita, Mahakali, Mahanilika, Matruvahaka, Meenakshi, Meghanada, Moksha, Mrugadurva, Rakshasi, Sadaladala, Sarpakshi, Trayanti, Uchhata, Urna, Vajrakanda, Vajri, Vandhya kanda, Vayasi, Vira, Vruntavari.

From the above list of plants with doubtful identity, 10 plant names which are frequently mentioned in the formulations and purification procedures have been considered for this study. Therefore, in this work those synonyms will be discussed one after the other as by available literature, taking help of the commentators of other works on Rasa-shastra. Wherever necessary the opinions of ancient commentators like Dalhana, Hemadri, Chakrapanidutta and modern commentators like Chunekar K.C, Kamat S.D, Bapalal Vaidya, Thakur Balwant Singh and Sharma P.V. are also considered.

Some other Nighantus have also given some plant names as given by Rasendra Mangala but in different context. Clarification is sought after duly regarding the opinions of the contemporary works.

\section{Results and Discussion}

The 10 drugs which are chosen for evaluation are discussed below:

\section{Kanchuki:}

In the context of Parada Murchana,(3) trituration of juice of Rajika, Kaipaya, Kakamaci, Mesashrungi, Krisna Dattura and Aranala is done with Kanchuki, Garudi, Varahika, etc, to attain Panchatva (Death). In Abhraka Satvapatana,(4) Abhraka Dhruti(5) and Loha Dhruti(6) also Kanchuki plant was mentioned.

Pandit Narahari opines that Yava - Hordeum vulgare Linn. which is one of the principle grains of India as 'Kanchuki'.(7) Acharya Kulkarni the author of Rasa Ratna Samucchaya quotes Dhanya in the process of Abhraka Satvapatana.(8)
This (Kanchuki) is a synonym applied for any cereal which is not yet husked. That is the reason many commentators form the Northern part of India equated it with Yava or Barley i.e. Hordeum vulgare Linn. If barley is not available, paddy or intact wheat can be used in its place. As the author Nagarjuna resided for most of his life and experimented with minerals and metals only in the southern part of India, it will be ideal in our opinion to consider Sali dhanya as Kanchuki.

\section{Chandali}

Flower juice of Chandali is used for the trituration of Parada, Swarna and Vaikranta bhasmas in the preparation of Vaikranta Garbha Rasa (9) which is indicated in the treatment of Mutrakricchra.

In Raja deepika commentary of Raja Nighantu it quotes Chandali as unidentified plant.(10) Though P.V. Sharma suggests in favour of some variety of Surana, in view of its anti - poisonous and rasayana properties, as one of the Dioscorea species should also not be ruled out.

As per Bhavamisra, a variety of Varahi kanda which is known as 'Ghrusti' in Western part of India is also known as 'Charmakara aluka'. (11) The Sanskrit equivalent of Chandala is charmakara. The outer layer of the bulbiferous roots of Dioscorea bulbifera Linn. look like a freshly taken out animal hive with hair follicles. That is the reason this plant can be better equated with Dioscorea bulbifera Linn. only, which contains large number of Phenolic compounds, Steroids and Calcium oxalates.(12) Also Dioscorea bulbifera is well indicated in Urinary tract infections (13) and hence must have been used in the preparation of Vaikranta Garbha Rasa.

\section{Coraka}

In the preparation of Pratapa lankeshwara ras,(14) Coraka along with some other drugs is triturated with buttermilk and this paste is rubbed over afflicted skin to cure all skin disorders is mentioned.

In the context of Candanadi Varga(15) of Raja Nighantu, Coraka is being mentioned as Pitta hara and having strong aroma.

The commentators of Charaka mention it with synonyms like Corapuspika, Corahuli (16) etc. This is identified as Angelica glauca Edgw. By Bapalal, Sharma P.V and Chunekar K.C (17) which belongs to Umbelliferae. It is called as 'Chora' in and around Punjab region which is now called as Choraka. (18)

Charaka mentions it in Sanjna sthapana dasemani (19) and considers the same.

This flowering of Angelica glauca is during late midnight, and colour of the flower is glowy, which is the exact period when dacoits / thieves start their functioning. Hence the name Coraka is implied to Angelica glauca Edgw. based on the nature of its flowering.

Also it can be confirmed Angelica glauca as Coraka for it being Pittahara and indicated in Skin disorders (20) which applies the same for the indication of Pratapa lankeshwara ras.

\section{Chandravalli}

In the preparation of Rasa bhasma,(21) Chandravalli along with some other drugs are triturated with Parada and Gandhaka to attain pisthika. 
This name is quite controversial. Chandravalli is the synonym of Prasarini(22) (Parpatadi Varga of Raja Nighantu) and Madhavi(23) (Karaveeradi Varga of Raja Nighantu) as mentioned by Pandit Narahari.

It is suggested to use Madhavi lata i.e., Hiptage benghalensis (L.)Kurz., as Chandravalli basing on its property of climbing in half moon shape (Chandrakara) as it is a woody climber and support from Raja Nighantu, where it is mentioned along with other varieties of flowers.

\section{Vayasi}

In the context of Deepana samskara of Parada, (24) Vayasi and some other drugs have been mentioned.

Two varieties of this drug are recognised. One is North-west Himalayan plant (Solanum dulcamara Linn.) and the next is Himalayan extended southwards (Solanum nigrum Linn). (25) Acharya Bhavamisra considers Kakamachi - Solanum nigrum Linn. as Vayasi. (26)

In the Text Amarakosa it is quoted that 'Kakamachi tu vayasi ityamarah'. (27)

Thakur Balwantji also opines that Kakamachi is Solanum nigrum Linn. (28)

Kakamaci is one of the plants belonging to 'Kakarastaka' which is the group of drugs prohibited from consumption while consuming metallic compounds after processing, (29) even then Kakamaci is used frequently in the preparation and processing of metallic compounds during their incineration (Marana).

\section{Meghanada}

Juice of Meghanada is used along with other plants in the preparation of Pundarika Kusthahara Rasa. (30)

Three kinds of Tandula recorded by Nighantus are Tanduliyaka, Tanduli bija, Meghanada where first variety is self-sown and other two varieties are cultivated. Kamat S.D equated Amaranthus tristis willd. as Meghanada. Amaranthus tristis is also called as Meghanada in the regions of Maharasthra.(31) According to A mbikadutta Sastry commentator on Rasa Ratna Samucchaya, mentioned Meghanada rasa under Jvara Chikitsa as 'Kantedar caulai' which is the Hindi name of A maranthus spinosus Linn. (32)

Prof. K.C. Chunekar mentions it under Shaka Varga as Amaranthus spinosus Linn. (33) He also quotes that Tanduliya or Caulai has so many varieties, according to number of spines and the colour of leaves i.e. green, red or mixed with blue.

Comparing its properties with the formulation of Pundarika kusthahara rasa, Amaranthus species is quoted to be Sita Virya and Pitta hara.(34)

When the rainy clouds start thundering, this tuberous grass appears to grow. Hence, it is known by the name of Meghanada. Correlating with its nature of occurrence Amaranthus spinosus Linn. is considered as Meghanada in this context.

\section{Vajrakanda}

While describing the process of Satvapatana of Vaikranta(35) and Sarvaloha kramana of Parada,(36) Vajrakanda is used along with some other plants.

Two species of plants are utilized by the workers for this purpose. Commentators like Kulkarni have suggested 'Vanasurana' which is a wild variety of
Corm (Kanda).(37) But Dalhana in his commentary on Sushruta equated it with 'Snuhi'. But in southern part of India 'Vanapalandu' is used in place of Vanasurana. P.V. Sharma also suggests Vajrakanda as Vanaplandu i.e. Urginia indica Kunth. belonging to family Liliaceae. (38) This plant is known as 'Vajjurkanda' in Madhya Pradesh.

Hence, our suggestion is that basing on the local synonym this plant can be considered as Urginia only; apart from the high content of Sulphur salts which are useful for purification of metals. Therefore in this context for processing, bulbs of Urginia Species is suggested.

\section{Sarpakshi}

Another plant drug named Sarpakshi is included as one among the plants in the preparation of Jaramrutyuharo Rasa(39) and Pundarika Kusthahara Ras.(40)

Many of the commentators like Dalhana, Arunadatta could not clarify the plant and opined conflictingly. Depending upon commentators and traditions prevalent in some parts of India, modern scholars like Thakur Balwant Singh have equated this plant with Ophiorrhiza mungos Linn. or some Rauwolfia species. (41) Morphologically some parts of this plant should resemble snake or snake with projecting eyes and tongue. Chunekarji in his work on Bhavaprakasha Nighantu mentions Sarpakshi as Ophiorrhiza mungos Linn. and quotes as 'Sarpakshiva puspamasyah' (42) which means its flowers resembles the eyes of snake. But neither of the two above species is fulfilling the said features. Hence there is a need to go on for another plant which is also used in Rasa-shastra.

In another context of same work Arisaema murrayi is equated with Nagini kanda.(43) Similarly it is ideal to consider another plant of same genera whose projecting spathe appears like snake's hood with a scaly appearance and two prominently growing red or white coloured oil glands on both sides looking like eyes. Arisaema candidissimus var. alba grows in Western Himalayas and is preferred here. It is known for its antipoisonous actions in local areas.

\section{Vira}

This plant name is mentioned under the process of Abhraka Satvapatana.(44)

Dalhana in his commentary quotes 'Kakoli vira sva namna prasiddah' under Kakolyadi gana of Susruta.(45)

Acharya P.V. Sharma considers Roscoea procera as Vira. Later Ashvagandha is advised to be substituted instead of Kakoli and Ksira kakoli due to unavailability of the drugs.(46) But, traditionally in Andhra Pradesh (northern parts) stem juice of Satavari is used to purify and calcinate metallic compounds like Abhraka. Vira is a synonym for Satavari also. Hence, in our opinion, Satavari (Asparagus racemosus Willd.) leaves can also be considered, wherever the word Vira is used.

\section{Kutheraka}

In the preparation of Pratapa lankeshwara ras (47) Kutheraka along with 16 other drugs are used for curing various skin disorders. 
Acharya P.V. Sharma mentions it as Vanatulasi variety (Ocimum sp.)(48) Bhavamisra considers that Kutheraka is the Sanskrit name of Vana tulasi / Barbari.(49) But later clarifies by differentiating three types of Barbari (Kutheraka, Arjaka and Vatapatra) where Kutheraka is Vana tulasi variety with black coloured flowers and Arjaka is with white flowers.

Dalhana in his commentary quotes 'Arjakah barbarikakaro laghu manjarikah sukshma patro nirgandha Svetakutherakah' clarifying that Arjaka is the white variety of Kutheraka.(50)

As per the opinion of Thakur Balwanth Singh he equated this plant with Orthosiphon grandiflorus Boldingh, Arjaka is called as 'Ajagura' in the nearby places of Banaras.(51)

Kutheraka is indicated in Dusta raktavikara (52) and the same is with Pratapa lankeshwara rasa which establishes its similarity in action wise between both.

Finally, due to its presence in many of the ancient texts along with the other Lamiaceae members and action wise similarity with the preparation in which it is used, this plant can be concluded as belonging to Orthosiphon species only.

\section{Conclusion}

Rasendra Mangala is one among the standard works accepted in the field of Rasashastra. It is both a work on processing of metals and also their utilization in treatment. Some plants mentioned in this work are not perfectly identified and posing a problem in the field of Rasa-shastra. Therefore, a trial work has been taken up, to rule out the existing confusion among some names of unknown origin. Nearly ten plants are discussed in this paper and their identity is proved. Further research work has to be carried out in order to find more unidentified plants of unknown origin.

The Identified plants with their possible botanical source and family is tabulated below

\begin{tabular}{|l|l|l|l|}
\hline $\begin{array}{l}\text { S. } \\
\text { No }\end{array}$ & Name & $\begin{array}{l}\text { Possible botanical } \\
\text { source }\end{array}$ & Family \\
\hline 1. & Kanchuki & Hordeum vulgare Linn. & Poaceae \\
\hline 2. & Chandali & $\begin{array}{l}\text { Dioscorea bulbifera } \\
\text { Linn. }\end{array}$ & Dioscoreaceae \\
\hline 3. & Coraka & Angelica glauca Edgw. & Apiaceae \\
\hline 4. & Chandravalli & $\begin{array}{l}\text { Hiptage benghalensis } \\
\text { Kurz. }\end{array}$ & Malpighiaceae \\
\hline 5. & Vayasi & Solanum nigrum Linn. & Solanaceae \\
\hline 6. & Meghanada & $\begin{array}{l}\text { Amaranthus spinosus } \\
\text { Linn. }\end{array}$ & $\begin{array}{l}\text { Amaranthacea } \\
\text { e }\end{array}$ \\
\hline 7. & Vajrakanda & Urginia species & Liliaceae \\
\hline 8. & Sarpakshi & $\begin{array}{l}\text { Arisaema candidissimus } \\
\text { var. }\end{array}$ & Araceae \\
\hline 9. & Vira & $\begin{array}{l}\text { Asparagus racemosus } \\
\text { Willd. }\end{array}$ & Liliaceae \\
\hline 10. & Kutheraka & Orthosiphon species & Lamiaceae \\
\hline
\end{tabular}

\section{References}

1. Garima Singhal, Riju Bhavesh, Kunal Kasariya, Ashish Ranjan Sharma, Rajendra Pal Singh. J Nanopart Res July 2011; 13:2981-2988.

2. https://www.researchgate.net/ publication/226350000

3. Mishra B.D and Mishra D.K. Rasendra Mangala of Acharya Nagarjuna with 'Gurjari' commentary. 1 ed. 2008. Karnataka; Aroor Ravi Memorial Ayurvedic Research Centre; 2008. Preface.

4. Mishra B.D and Mishra D.K. Rasendra Mangala of Acharya Nagarjuna with 'Gurjari' commentary. 1 ed. 2008. Karnataka; Aroor Ravi Memorial Ayurvedic Research Centre; 2008. 25p.

5. Mishra B.D and Mishra D.K. Rasendra Mangala of Acharya Nagarjuna with 'Gurjari' commentary. 1 ed. 2008. Karnataka; Aroor Ravi Memorial Ayurvedic Research Centre; 2008. 41p.

6. Mishra B.D and Mishra D.K. Rasendra Mangala of Acharya Nagarjuna with 'Gurjari' commentary. 1 ed. 2008. Karnataka; Aroor Ravi Memorial Ayurvedic Research Centre; 2008. 47p.

7. Mishra B.D and Mishra D.K. Rasendra Mangala of Acharya Nagarjuna with 'Gurjari' commentary. 1 ed. 2008. Karnataka; Aroor Ravi Memorial Ayurvedic Research Centre; 2008. 48p.

8. Satish Chandra Sankhyadhar and Dr. Deepika Sankhyadhar. Sri Narahari Pandit's Raja Nighantu. Varanasi; Chaukhambha Orientalia; 2012. 869p.

9. Dattatreya Anantha Kulkarni. Rasa Ratna Samucchaya of Vagbhatacharya with 'Vijnana bodhini' commentary. New Delhi; Meharchand Lakshmandas Publications; 2010. 24p.

10. Mishra B.D and Mishra D.K. Rasendra Mangala of Acharya Nagarjuna with 'Gurjari' commentary. 1 ed. 2008. Karnataka; Aroor Ravi Memorial Ayurvedic Research Centre; 2008. 146p.

11. Satish Chandra Sankhyadhar and Dr. Deepika Sankhyadhar. Sri Narahari Pandit's Raja Nighantu. Varanasi; Chaukhambha Orientalia; 2012. 320p.

12. Padmashree Prof. Chunekar K.C. Bhavaprakasha Nighantu of Bhavamisra with Commentary. Varanasi; Chaukambha Bharathi Academy; 2015. 372p.

13. Sanjeet Kumar, Gitishree Das, Han-Seung Shin and Jayanta Kumar Patra. Front. Pharmacol. $14^{\text {th }}$ Feb 2017; doi: 10.3389/fphar.2017.00052

14. Bulusu Sitaram. Bhavaprakasha of Bhavamisra. Varanasi; Chaukambha Orientalia; 2018. 275p.

15. Mishra B.D and Mishra D.K. Rasendra Mangala of Acharya Nagarjuna with 'Gurjari' commentary. 1 ed. 2008. Karnataka; Aroor Ravi Memorial Ayurvedic Research Centre; 2008. 91p.

16. Satish Chandra Sankhyadhar and Dr. Deepika Sankhyadhar. Sri Narahari Pandit's Raja Nighantu. Varanasi; Chaukhambha Orientalia; 2012. 695p.

17. niimh.nic.in (National Institute of Indian Medical Heritage), CCRAS, Ministry of Ayush, Gov. of India.

18. http://niimh.nic.in/ebooks/esushruta/?mod=read

19. Padmashree Prof. Chunekar K.C. Bhavaprakasha Nighantu of Bhavamisra with Commentary. Varanasi; Chaukambha Bharathi Academy; 2015. $244 \mathrm{p}$.

20. Satish Chandra Sankhyadhar and Dr. Deepika Sankhyadhar. Sri Narahari Pandit's Raja Nighantu. 
Varanasi; Chaukhambha Orientalia; 2012. 696p.

21. Sharma P.V. Plants and other drugs of Caraka Samhita Saptadhyayi. Delhi; Rasthriya Ayurveda Vidyapeeth; 2002. 155p.

22. Bulusu Sitaram. Bhavaprakasha of Bhavamisra. Varanasi; Chaukambha Orientalia; 2018. 223p.

23. Mishra B.D and Mishra D.K. Rasendra Mangala of Acharya Nagarjuna with 'Gurjari' commentary. 1 ed. 2008. Karnataka; Aroor Ravi Memorial Ayurvedic Research Centre; 2008. 155p.

24. Satish Chandra Sankhyadhar and Dr. Deepika Sankhyadhar. Sri Narahari Pandit's Raja Nighantu. Varanasi; Chaukhambha Orientalia; 2012. 155p.

25. Satish Chandra Sankhyadhar and Dr. Deepika Sankhyadhar. Sri Narahari Pandit's Raja Nighantu. Varanasi; Chaukhambha Orientalia; 2012. 515p.

26. Mishra B.D and Mishra D.K. Rasendra Mangala of Acharya Nagarjuna with 'Gurjari' commentary. 1 ed. 2008. Karnataka; Aroor Ravi Memorial Ayurvedic Research Centre; 2008. 27p.

27. Kamat S.D. Studies on Medicinal Plants and Drugs in Dhanvantari Nighantu. Varanasi; Chaukamba Sanskrit Pratisthan; 2002. 286p.

28. Bulusu Sitaram. Bhavaprakasha of Bhavamisra. Varanasi; Chaukambha Orientalia; 2018. 295p.

29. Dattatreya Anantha Kulkarni. Rasa Ratna Samucchaya of Vagbhatacharya with 'Vijnana bodhini' commentary. New Delhi; Meharchand Lakshmandas Publications; 2010. 234p.

30. Vishwanath Jha. Amarakosha. 3ed. Varanasi; Motilal Banarasidas; 1979. 85p.

31. Thakur Balwant Singh. Glossary of Vegetable drugs in Bruhattrayi. 2015ed. Varanasi; Chaukambha Prakashan; $2015.87 \mathrm{p}$.

32. Mishra B.D and Mishra D.K. Rasendra Mangala of Acharya Nagarjuna with 'Gurjari' commentary. 1 ed. 2008. Karnataka; Aroor Ravi Memorial Ayurvedic Research Centre; 2008. 82p.

33. Kamat S.D. Studies on Medicinal Plants and Drugs in Dhanvantari Nighantu. Varanasi; Chaukamba Sanskrit Pratisthan; 2002. 355p.

34. Sri Ambikadutta Sastry. Rasa Ratna Samuchchaya of Vagbhatacharya. Varanasi; Chaukambha Amarabharathi Prakashan; 2014. 223p.

35. Kamat S.D. Studies on Medicinal Plants and Drugs in Dhanvantari Nighantu. Varanasi; Chaukamba Sanskrit Pratisthan; 2002. 355p

36. Padmashree Prof. Chunekar K.C. Bhavaprakasha Nighantu of Bhavamisra with Commentary. Varanasi; Chaukambha Bharathi Academy; 2015. $654 \mathrm{p}$.

37. Mishra B.D and Mishra D.K. Rasendra Mangala of Acharya Nagarjuna with 'Gurjari' commentary. 1 ed. 2008. Karnataka; Aroor Ravi Memorial Ayurvedic Research Centre; 2008. 42p.

38. Mishra B.D and Mishra D.K. Rasendra Mangala of
Acharya Nagarjuna with 'Gurjari' commentary. 1 ed. 2008. Karnataka; Aroor Ravi Memorial Ayurvedic Research Centre; 2008. 161p.

39. Dattatreya Anantha Kulkarni. Rasa Ratna Samucchaya of Vagbhatacharya with 'Vijnana bodhini' commentary. New Delhi; Meharchand Lakshmandas Publications; 2010. 48p.

40. Sharma P.V. Dravyaguna Vijnana Vol 2. Varanasi; Choukambha Bharathi Academy; 2018. 206p.

41. Mishra B.D and Mishra D.K. Rasendra Mangala of Acharya Nagarjuna with 'Gurjari' commentary. 1 ed. 2008. Karnataka; Aroor Ravi Memorial Ayurvedic Research Centre; 2008. 72p.

42. Mishra B.D and Mishra D.K. Rasendra Mangala of Acharya Nagarjuna with 'Gurjari' commentary. 1 ed. 2008. Karnataka; Aroor Ravi Memorial Ayurvedic Research Centre; 2008. 82p.

43. Thakur Balwant Singh. Glossary of Vegetable drugs in Bruhattrayi. 2015ed. Varanasi; Chaukambha Prakashan; 2015. 426p.

44. Padmashree Prof. Chunekar K.C. Bhavaprakasha Nighantu of Bhavamisra with Commentary. Varanasi; Chaukambha Bharathi Academy; 2015. $438 \mathrm{p}$.

45. Sharma P.V. Dravyaguna Vijnana Vol 5. 1ed. Varanasi; Choukambha Bharathi Academy; 2017. $351 \mathrm{p}$.

46. Mishra B.D and Mishra D.K. Rasendra Mangala of Acharya Nagarjuna with 'Gurjari' commentary. 1 ed. 2008. Karnataka; Aroor Ravi Memorial Ayurvedic Research Centre; 2008. 41p.

47. niimh.nic.in (National Institute of Indian Medical Heritage), CCRAS, Ministry of Ayush, Gov. of India. Available from: http://niimh.nic.in/ebooks/ esushruta/?mod=read

48. Sharma P.V. Plants and other drugs of Susruta Samhita Saptadhyayi. Delhi; Rasthriya Ayurveda Vidyapeeth; 2002. 12p.

49. Mishra B.D and Mishra D.K. Rasendra Mangala of Acharya Nagarjuna with 'Gurjari' commentary. 1 ed. 2008. Karnataka; Aroor Ravi Memorial Ayurvedic Research Centre; 2008. 91p.

50. Sharma P.V. Plants and other drugs of Susruta Samhita Saptadhyayi. Reprint ed. Delhi; Rasthriya Ayurveda Vidyapeeth; 2002. 12p.

51. Bulusu Sitaram. Bhavaprakasha of Bhavamisra. Varanasi; Chaukambha Orientalia; 2018. 335p.

52. Sharma P.V. Plants and other drugs of Susruta Samhita Saptadhyayi. Reprint ed. Delhi; Rasthriya Ayurveda Vidyapeeth; 2002. 34p.

53. Thakur Balwant Singh. Glossary of Vegetable drugs in Bruhattrayi. Revised ed. Varanasi; Chaukambha Prakashan; 2015. 103p.

54. Kamat S.D. Studies on Medicinal Plants and Drugs in Dhanvantari Nighantu. Varanasi; Chaukamba Sanskrit Pratisthan; 2002. 304p. 